УДК 681.586 .4

М. Г. Томенко, к.пед.н., доиент,

e-mail: marina_tomenko@ukr.net

Черкаський інститут пожежної безпеки імені Героїв Чорнобиля

Національного університету цивільного захисту України

вул. Онопрієнка, 8, м. Черкаси, 18034, Україна

О. О. Корецька, асистент

e-mail: alex.koretska@chmnu.edu.ua

Чорноморський національний університет імені Петра Могили вул. 68 Десантників, 10, м. Миколаїв, 54003, Україна

\title{
ВИКОРИСТАННЯ КОНСОЛЬНИХ П'ЄЗОКЕРАМІЧНИХ ІДЕНТИФІКАТОРІВ У ВІБРОДІАГНОСТИЦІ ПРИ ВИЗНАЧЕННІ АВАРІЙНИХ СИТУАЦІЙ ПОТЕНЦІЙНО НЕБЕЗПЕЧНИХ ВИРОБНИЦТВ
}

У статті розглядається можливість ідентифікації технологічного обладнання, щзо може бути використане в системі визначення аварійних ситуацій потенційно небезпечних виробниитв. Для иього в роботі запропоновано використовувати консольні п'єзоперетворювачі на базі асиметричних біморфних п'єзоелементів. Зміною розмірів та форм електродів на протилежних сторонах тонкого п'єзоелемента досягається зміна характеристик n'єзоперетворювача, що слугує ідентифікатором перетворювача, а отже, $і$ обладнання, на якому він закріплений. Причому, площі електродів на протилежних сторонах не перетинаються, що забезпечує умови виникнення доменно-дисипативних властивостей п'єзоелемента.

Ключові слова: аварійні ситуачії, консольні доменно-дисипативні п'єзоперетворювачі, ідентифікаиія обладнання

Вступ. Визначення аварійних ситуацій та аварій на ранніх стадіях у типових технологічних процесах, пов'язаних 3 хімічною, радіаційною та пожежовибухонебезпекою, є важливим питанням в запобіганні виникненню та ліквідації наслідків надзвичайних ситуацій техногенного характеру.

У більшості випадків аварії на потенційно-небезпечних об'єктах (ПНО) або об'єктах підвищеної небезпеки (ОПН) відбуваються не через форс-мажорні обставини, такі як цунамі, землетрус, військова агресія тощо, а внаслідок порушення (зміни) технологічного процесу через поломку обладнання або недбале управління (людський фактор). В таких випадках аварія, як правило, не відбувається миттєво - ій передують деякі зміни в роботі обладнання, які можуть бути визначені на ранніх стадіях. Зміна в роботі обладнання призводить до змін струмів, механічних обертів тощо, що супроводжується зміною теплової картини нагріву окремих елементів, а також зміною механічних коливань агрегатів. Зміну теплової картини фіксують за допомогою тепловізорів. Такий спосіб добре зарекомендував себе у визначенні бракованих електричних плат, де легко фіксується зміна нагріву радіоелементів при зміні проходження через них струмів. Метод термо- фіксації на ПНО та ОПН у більшості випадках не є дієвим, оскільки робочі агрегати більшості небезпечних об'єктів вкриті корпусами, що ускладнює процес отримання термокартини. Крім того, у випадку пожежі наявний дим повністю заблокує отримання будь-якої візуальної картини.

Іншим методом фіксації відхилень у роботі ПНО та ОПН є зміна вібраційної картини. На рис. 1 наведено приклад використання віброгенератора Volture на промисловій установці [1].

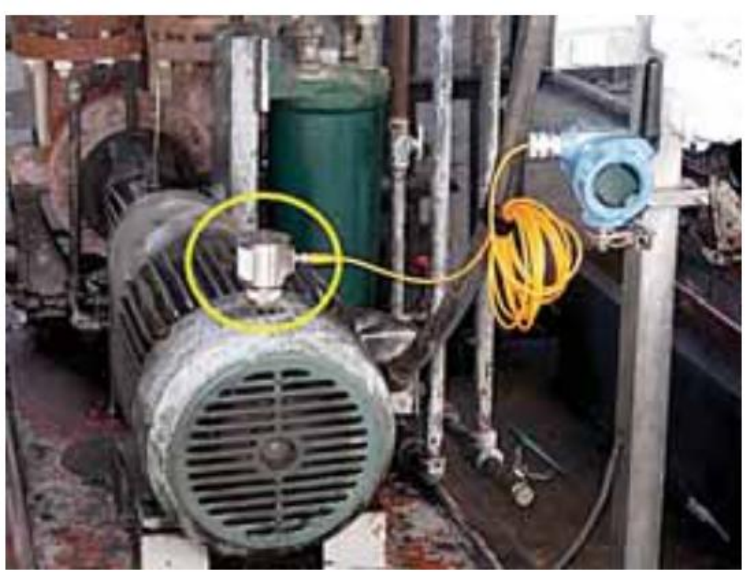

Рис. 1. Установка віброгенератора Volture на промисловому двигуні [1] 
Наявність відхилень у вихідному струмі віброгенератора слугує показником характеру функціонування і стану контрольованого обладнання.

Як такі датчики вібрацій найчастіше використовують п'єзокерамічні перетворювачі $[1,2]$. Проте при такому методі фіксацій у відхиленні роботи обладнання ПНО та ОПН виникає декілька технічних питань:

- спосіб передачі інформації від датчиків вібрацій;

- можливість ідентифікації пошкодженого обладнання при їх великій чисельності;

- чутливість датчиків для фіксації малих відхилень вібрацій.

Перша задача легко розв'язується за допомогою використання бездротового зв'язку, хоча це і призводить до подорожчання загальної системи контролю.

Для ідентифікації об' єктів (друга задача), які можна зчитувати дистанційним способом, у логістиці та на виробництві найчастіше використовують RFID (Radio Frequency Identification). Проте наявні в RFIDпередавачах мікроконтролери чутливі до сильних радіовипромінювань, що обмежує їх застосування в зонах дії великих небажаних радіочастотних випромінювань, якими як раз i характеризуються промислові ПНО та ОПН. В цьому випадку рішенням $\epsilon$ застосування радіочастотної ідентифікації на поверхневих акустичних хвилях (ПАХ), що так само здійснюється на п'єзокерамічних елементах [3]. Конструкцію такого ідентифікатора зображено на рис. 2.

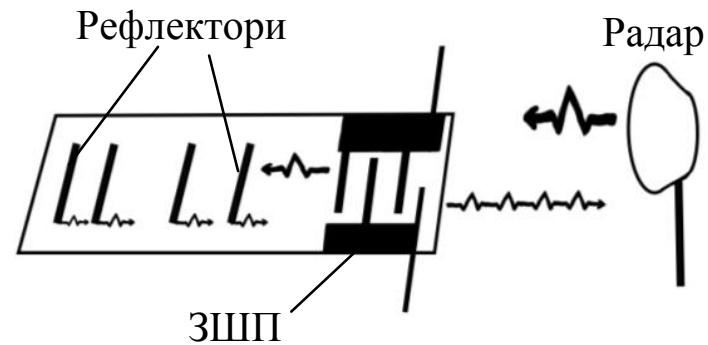

\section{Рис. 2. Радіочастотний п’єзоідентифікатор на ПАХ}

Радар випромінює радіочастотний сигнал. На поверхні п'єзопластини нанесений зустрічно-штировий перетворювач (ЗШП), за допомогою якого, через прямий п'єзоефект, електромагнітні коливання сигналу перетворюються на механічні коливання п'єзопластини. На поверхні пластини нанесені металеві смуги, що слугують рефлекторами і відбивають сигнал. Відбитий сигнал, завдяки зворотному п'єзоефекту та ЗШП, перетворюється на радіочастотний сигнал, який фіксується радаром. Завдяки різним відстаням між металевими смугами (рефлекторами) формується різний радіочастотний сигнал, що слугує ідентифікатором перетворювача.

Для вирішення третьої задачі - підвищення чутливості датчиків - одним із авторів було запропоновано виконання п'єзодатчиків вібрації у вигляді консольних доменнодисипативних п'єзокерамічних перетворювачів $[4,5]$. Проте такі перетворювачі побудовані на основі круглих біморфних п'єзоперетворювачів, у той час як ідентифікатори на основі ПАХ виконані на мономорфній тонкій подовжній п'єзопластині.

Таким чином, метою роботи є розробка методу ідентифікації на основі консольних п'єзокерамічних перетворювачів, що може бути використаний у системі визначення аварійних ситуацій потенційно небезпечних виробництв.

Основна частина. Відомо, що, порівняно з мономорфними п'єзоперетворювачами, набагато більшу чутливість (у 10-20 разів) мають асиметричні біморфні перетворювачі. Вони відрізняються простішою технологією виготовлення, більшою механічною міцністю і складаються 3 металевої пластини 3 приклеєним до неї плоским п'єзоелементом [2].

Крім того, збільшення чутливості можна досягти при використанні доменнодисипативних властивостей п'єзоелемента, коли вектор напруженості поля вихідного сигналу практично перпендикулярний вектору поляризації кераміки $[2,5]$. Цього ефекту можна досягти зміною форм електродів на сторонах п'єзоелемента. Крім того, для ідентифікації п'єзоперетворювачів у роботі запропоновано змінювати форми та площі електродів при виконанні головної вимоги: вектор напруженості поля вихідного сигналу повинен наближатися до нормалі до вектора поляризації кераміки. Цього можна досягти, якщо елек- 
троди на протилежних гранях не будуть перетинатися (рис. 3).

На рис. 3 показано два варіанти доменно-дисипативних перетворювачів: на металевій пластині 1 закріплений тонкий круглий поляризований по товщині п'єзоелемент 2, на якому закріплені 3 різних сторін п'єзоелемента електроди 3 та 4. Оскільки площі електродів 3 різних сторін не перетинаються, вектор напруженості вихідного поля буде завжди наближатися до нормалі до вектора поляризації, забезпечуючи доменнодисипативні властивості п'єзоперетворювача $[2,5]$.

a)

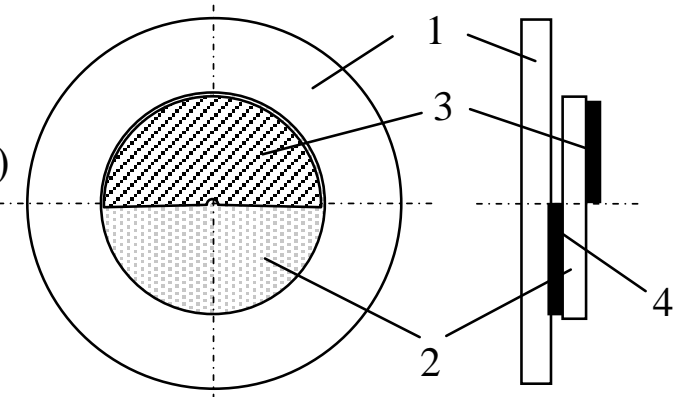

б)



Рис. 3. Доменно-дисипативні асиметричні п'єзоперетворювачі

Як відомо, різна форма та розміри електродів приводять до зміни як чутливості, так і значень резонансної частоти [2]. Таким чином, зміною розмірів та форм електродів можна змінювати властивості перетворювачів, що забезпечить їх ідентифікацію, а отже, й ідентифікацію обладнання, на якому вони закріплені.

В експериментальному дослідженні було поставлено задачу ідентифікації трьох асиметричних п'єзоперетворювачів. Для цього були вибрані п'єзоелементи 7BВ-12-9 фір- ми muRata [6], що складаються 3 металевої пластини 3 латуні діаметром 12 мм та товщиною $0,1 \mathrm{~mm}$ із закріпленим на ній п'єзоелементом діаметром 9 мм та товщиною 0,12 мм. Резонансна частота - 9 кГц, ємність 8 нФ, вага - 0,143 г.

Для імітації передачі вібрації використано оцинковану стальну пластину марки 08 пс/3сп розмірами $35 \times 20 x 0,4$ мм, на якій було закріплено три досліджувані п'єзоелементи (ідентифікатори) та вихідний п'єзоелемент, 3 якого знімався сигнал. Пластина була закріплена консольно (з одного боку пластини). Як джерело вібрації виступив мотор AMS1141M 3 асиметричним навантаженням на валу. Конструкцію експериментальної установки показано на рис. 4.

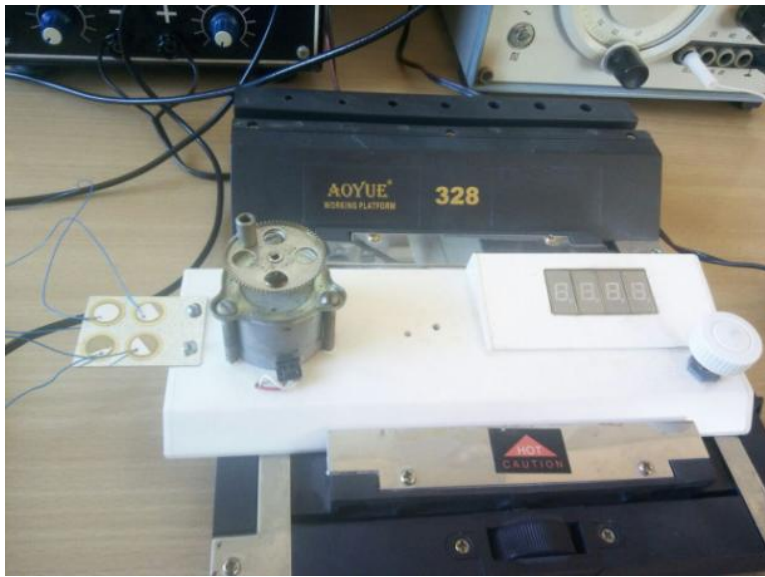

Рис. 4. Експериментальна установка

Вібраційна платформа була зафіксована за допомогою AOYUE328. Як джерело живлення використано прилад Lips2010. Для створення та вимірювання параметрів вібрації використано осцилограф SDS1052DL+, генератор Г3-106, мілівольтметр В3-38.

На трьох п’єзоелементахідентифікаторах були виконані електроди різних форм за умови неперетинання площ протилежних граней: третина площі, половина, та дві третини.

Проведені експерименти показали, що зміна напруги на кожному 3 трьох п'єзоелементів викликала зміну напруги та форми вихідного сигналу на четвертому - вихідному п'єзоелементі. Причому, завдяки різним характеристикам п'єзоелементів- 
ідентифікаторів вдалося однозначно визначити, на який із трьох п'єзоелементів подавалася напруга.

Таким чином, зміна вібрації обладнання, яка виникне через зміну його робочого процесу, буде передана п'єзоперетворювачу, що закріплений на досліджуваному обладнанні. Переданий від п'єзоперетворювача сигнал буде однозначно ідентифікований, а отже, буде ідентифіковане обладнання, яке змінило свій робочий режим. Це дає можливість визначення аварійних ситуацій потенційно небезпечних виробництв на їх ранніх стадіях

\section{Список літератури}

1. Бугаев В. И., Дидук В. А., Мусиенко М. П. Сборщики энергии вибраций от Mide Technology приходят на смену батарейкам. Новости электроники. Москва, 2015. № 7 (141). C. 23-27.

2. Шарапов В. М., Мусиенко М. П., Шарапова Е. В. Пьезоэлектрические датчики: монография / под ред. В. М. Шарапова. Москва: Техносфера, 2006. 632 с.

3. Система радиочастотной идентификации на поверхностных акустических волнах. Компоненты и технологии. URL: http://kite.ru/articles/rfid/2005_6_188.php

4. Мусієнко М. П., Корецька О. О. Консольні п’єзоелектричні накопичувачі вібрації для ІоТ пристроїв. Наукові прачі [Чорномор. наи. ун-ту ім. Петра Могили комплексу «Києво-Могилянська академія»]. Серія: Комп'ютерні технології: наук.-метод журн. Миколаїв: ЧНУ, 2017. Т. 308. Вип. 296. С. 139-145.

5. Мусієнко М. П., Корецька О. О. Підвищення чутливості датчиків п'єзомагнітних тахометрів. Датчики, прилади та системи - 2018: матеріали VII Міжнар. наук.-практ. конф., 17-21 верес. 2018 р. Черкаси: ЧДТУ, 2018. C. 9-12.

6. Murata. Innovator in electronics. 7bb-12-9. URL: https://www.murata.com/products/ productdetail?partno=7BB-12-9

\section{References}

1. Bugaev, V. I., Diduk, V. A., Musienko, M. P. (2015) Vibration energy collectors from Mide Technology replace batteries. Novosti elektroniki, No. 7 (141), Moscow, pp. 23-27 [in Russian].

2. Sharapov, V. M., Musienko, M. P., Sharapova, V. V. (2006) Piezoelectric sensors: monograph / Ed. V. M. Sharapov. Moscow: Tehnosfera, 632 p. [in Russian].

3. The radio frequency identification system on surface acoustic waves. Komponentyi $i$ tehnologii. URL: http://kit-e.ru/articles/rfid/ 2005_6_188.php

4. Musienko, M. P., Koretska, O. O. (2017) Console piezoelectric vibration drives for IoT devices. Naukovi praci [Chornomor. nacz. untu im. Petra Mogyly kompleksu «KyevoMogylyans 'ka akademiya»]. Seriya : Komp'yuterni tepnologiyi: sci.-method. journ., vol. 308, iss. 296. Mykolayiv: ChNU, pp. 139145 [in Ukrainian].

5. Musienko, M. P., Koretska, O. O. (2018) The increase of sensitivity of piezomagnetic tachometers sensors. Datchyky, prylady ta systemy - 2018: materials of the VII International sci.-pract. conf., Sept. 17-21. Cherkasy: ChDTU, pp. 9-12 [in Ukrainian].

6. Murata. Innovator in electronics. 7bb-12-9. URL: https://www.murata.com/products/ productdetail?partno=7BB-12-9 
M. G. Tomenko, $P h D$, associate professor,

Cherkasy Institute of Fire Safety named after Chornobyl Heroes

of National University of Civil Defense of Ukraine

Onoprienko str., 8, Cherkasy, 18034, Ukraine e-mail: marina_tomenko@ukr.net

O. O. Koretska, assistant

Petro Mohyla Black Sea National University

68-Desantnykiv str., 10, Mykolayiv, 54003, Ukraine

e-mail: alex.koretska@chmnu.edu.ua

\section{USE OF CONSOLE PIEZOCERAMIC IDENTIFIERS \\ IN VIBRODIAGNOSTICS AT THE DEFINITION OF EMERGENCY SITUATIONS OF POTENTIALLY HAZARDOUS PRODUCTIONS}

The article discusses the possibility of identifying technological equipment that can be used in the system for determining emergency situations of potentially hazardous industries. For this purpose, it is offered to use console piezoelectric transducers based on asymmetric bimorph piezoelectric elements. By changing the size and shape of the electrodes on opposite sides of a thin piezoelectric element, a change in the characteristics of piezoelectric transducer is achieved, which serves as an identifier for the transducer, and hence for the equipment on which it is attached. Moreover, the areas of the electrodes on opposite sides do not intersect, which provides the conditions for the occurrence of domain-dissipative properties of piezoelectric element.

Keywords: emergency situations, console domain-dissipative piezotransducers, equipment identification. 